\title{
Allelopathic Evaluation of Euphorbia parviflora L. Aqueous Leachates on Wheat (Triticum aestivum L.)
}

\author{
B K Avchar*
}

Vidya Pratishthan's Arts, Science and Commerce College, Vidyanagari, Baramati, Dist-Pune (M.S.), India

DOI: $10.36347 /$ sajb.2020.v08i04.001

| Received: 31.03.2020 | Accepted: 07.04.2020 | Published: 08.04.2020

*Corresponding author: B K Avchar

Abstract

Original Research Article

Allelopathy is the direct or indirect effect of one plant on another through release of substances in the environment and occurs widely in natural plant communities. The secondary metabolites or natural products involved in allelopathy are called allelochemicals and can be produced in different parts of the plants. The purpose of this study was to evaluate the allelopathic activity of medicinal plant weed Euphorbia parviflora L on Wheat (Triticum aestivum L.) crop. Laboratory bioassay was conducted and biochemical parameters were determined. The root, stem and leaf leachates inhibited the germination percentage and seedling growth of wheat. The allelopathic effect varied in each of the tests and this depends upon type of plant material used for bioassay. All the types of leachates suppress the growth of radicle significantly. The effect on seed germination was more pronounced in leachates of root and stem while there was little effect by leaf leachates. The germination was considerably inhibited as well as delayed by the root and stem leachates. However, the magnitude of inhibition of leachates followed the order stem $>$ leaf $>$ root. The plant was chemically analyzed for the presence and confirmation of Caffeic acid by HPTLC method. Preliminary phytochemical tests were carried out for the confirmation of some secondary metabolites in the plant parts. The inhibitory effects of Euphorbia parviflora L. on wheat may be due to the presence of Caffeic acid, Saponins and Tannins as allelochemicals in the leachates.

Keywords: Allelopathy, Euphorbia parviflora, Triticum aestivum.

Copyright @ 2020: This is an open-access article distributed under the terms of the Creative Commons Attribution license which permits unrestricted use, distribution, and reproduction in any medium for non-commercial use (NonCommercial, or CC-BY-NC) provided the original author and source are credited

\section{INTRODUCTION}

The concept that one plant can influence the growth of another is well known in agriculture. The secondary metabolites produced by plants (donor) when released in to the environment play a vital role in ecology, physiology and growth of another plants (recipient) in their vicinity. Many a times, leached chemicals from the plants have allelopathic influence on the germination and growth of subsequent crops [1-5]. Leachates are the removal of substances from plants by the action of aqueous solvents. All plants seem to be leachable, although the degree depends on type of tissue, stage of maturity and type, amount and duration of precipitation [6]. A large diversity of allelopathic compounds are leached, both organic and inorganic compounds such as phenolic acids, terpenoids and alkaloids [7].

Euphorbia parviflora $L$. belongs to family Euphorbiaceae. The plant is an annual herb growing erect upto $15-30 \mathrm{~cm}$. in height. It is a very common weed usually associated with Wheat, Jawar, Safflower, and adversely affect the crop growth and yields. Leaves are elliptic to oblong, with obtuse apex and rounded base. Involucres with white or rarely pinkish red petaloid limbs. Fruit is capsule type, capsules are subglobose and hairy. Seeds are reddish brown. Flowers and fruits are found in the months of July to February [8]. The dominance of the weed is more than $60 \%$. It has some medicinal values as it is useful in dysentery and diarrhoea [9]. Infusion of dried leaves is astringent used in dysentery, diarrhoea, menorrhagia and leucorrhoea [9]. It contains phenolic substances, essential oil, glycosides and alkaloids [10].

Mathela et al. [11] reported that the secondary metabolites of many medicinal plants are responsible for allelopathic activity. We want to find out the allelopathic potential of medicinal weed plant succeeding crop. This investigation was aimed to study the behavior of phytochemicals present in Euphorbia parviflora L. leachates on germination and seedling growth of wheat crop. 


\section{MATERIAL AND METHODS}

\section{Leachates Bioassay}

Healthy and mature Euphorbia parviflora L. plants were collected from agricultural fields of Shirur Tahasil in Pune district (M.S.). The freshly collected plants were washed with distilled water so as to remove soil particles and used for bioassays. The Petriplates bioassay consisted three factors (a) soaking periods of plants for preparing leachates $(48,72 \mathrm{~h})$, (b) aqueous leachates of three parts of Euphorbia parviflora and (c) two concentrations $(25,50 \%)$. The collected plants were separated and chopped into $2-3 \mathrm{~cm}$ long pieces. Fresh leaves, stem and roots at $100 \mathrm{~g}$ each were soaked separately in $250 \mathrm{ml}$ distilled water in two different sets i.e. set A ( soaked for $48 \mathrm{~h}$ ) and set B ( soaked for $72 \mathrm{~h}$ ). The leachates were filtered through Whatman No. 1 filter paper and $100 \mathrm{ml}$ of each leachate was diluted to 25 and $50 \%$ using distilled water. The leachates were stored in refrigerator at $4^{\circ} \mathrm{C}$ and used up to 7 days.

In order to study whether these leachates of medicinal plant weed used show allelopathic effect on test crop, surface sterilized 10 seeds of wheat (Triticum aestivum L.) were placed in sterilized Petridish $(11 \mathrm{~cm}$ diameter) containing Whatman No. 1 filter paper. $10 \mathrm{ml}$ of each leachates solution were used for moistening filter paper. Each Petridish containing 10 seeds of wheat were kept in triplicate at room temperature $\left(28 \pm 2^{\circ} \mathrm{C}\right)$. A Petridish containing Whatman No.1 filter paper moistened with distilled water served as control. These Petridishes were wrapped by brown paper so as to avoid direct sunlight. The seeds were allowed to germinate for 8 days. Germination was recorded on $7^{\text {th }}$ day, using emergence of radical as criteria for germination count. On $8^{\text {th }}$ day, seedling length in terms of hypocotyls and radical length were recorded.

\section{Phytochemical Tests}

Preliminary photochemical tests were carried out for the confirmation of Starch [12], Proteins [13], and Tannins [13], Saponins [13], Reducing sugars and Anthroquinones [14] in water extractives, while Alkaloids, Glycosides and Flavanoids in alcoholic extractives.

\section{High Performance Thin Layer Chromatography (HPTLC) Analysis}

The allelochemicals constituents were also confirmed with the help of HPTLC method [15]. HPTLC is a versatile separation technique included various steps as given below:

i) Selection of HPTLC plates and sorbent

ii) Sample preparation.

iii) Application of sample

iv) Development (separation)

v) Detection including post-chromatographic derivable

vi) Quantitation

vii) Documentation

\section{RESULTS AND DISCUSSION}

The aqueous leachates of root stem and leaves of Euphorbia parviflora caused significant reduction in seed germination and seedling growth of test crop. The higher inhibitory effect was found in stem leachates as compared to leaves and root leachates. The radical length was more affected than hypocotyl growth in all three types of leachates. The stem leachates not only reduced seed germination but also have pronounced decrease in seedling growth of wheat. In stem and root leachates the seed germinations were reduced to $32 \%$ and $68 \%$ respectively. However, the magnitude of inhibition of leachates followed the order: stem $>$ leaf $>$ root.

The leachates of Euphorbia parviflora also caused significant reduction in seed germination and seedling growth of wheat. The inhibition was similar in both soaking periods and concentrated stem leachates caused maximum reduction. The reduction of germination percentage was correlated with reduced seedling growth. The stem and leaf leachates of Euphorbia parviflora inhibited seed germination as well as reduced seedling growth of wheat. This may be due to phytotoxic activity of phytochemicals present in aqueous leachates of Euphorbia parviflora. The degree of inhibition depends on the concentration of leachates even in soaking period of 72 hours. Among all the test leachates, dilute root leachates had no significant inhibitory effects in both the soaking periods.

Phytochemical analysis of Euphorbia parviflora has revealed that root, stem and leaves extract with water and alcohol shows presence of Tannins, Saponins and alkaloids respectively.

Root and stem water extracts shows positive tests for saponins, alkaloids and flavanoids. Starch, proteins, anthroquinones, and reducing sugars are not detected in any plant part. The radical length was more hampered than hypocotyl elongation in all three leachates. This might be due to the presence of saponins, glycosides and alkaloids. These phytochemicals might be responsible for allelopathic potential of the weeds. The dark brown colour of leachates also indicates the presence of simple Phenolics, which are commonly, identified allelochemicals in higher plants [5].

\section{CONCLUSION}

With the help of HPTLC technique Caffeic acid was identified and confirmed from Euphorbia parviflora leaves. However, all the above said phytochemicals were phytotoxic. These results revealed that the leachates of Euphorbia parviflora contain water soluble phytotoxic chemicals and when released cause inhibitory effects on neighboring plants. Hence precautions should be taken while growing the wheat crop in Euphorbia parviflora fields. The leachates of decomposed leaf litter present in the field after its harvest, may cause a major damage to 
succeeding crops, hence leaf litter should be completely removed before sowing the next crop.

\section{ACKNOWLEDGEMENT}

The author is thankful to Head of the Department of Botany and Principal of Vidya Pratishthan's Arts, Science and Commerce College, Vidyanagari, Baramati, Dist-Pune (M.S.), India for providing necessary facilities to carry out the research work.

Table-1: Table showing Results of Inhibitory effect of Leachates of Euphorbia parviflora $\mathbf{L}$

\begin{tabular}{|c|c|c|c|}
\hline Type of leachates & Germination (\%) & \multicolumn{2}{|c|}{$\begin{array}{c}\text { Average Seedling length of } \\
\text { Wheat (cm) }\end{array}$} \\
\cline { 3 - 4 } & & Radical & Hypocotyl \\
\hline Control & 95.45 & 6.180 & 5.070 \\
\hline Root & 68.85 & 1.785 & 2.100 \\
\hline Stem & 32.14 & 0.933 & 1.300 \\
\hline Leaf & 72.16 & 1.228 & 2.685 \\
\hline
\end{tabular}

Graph showing inhibitory effects of Leachates of Euphorbia parviflora L.

mermiation \% vadical length wypocotyl length
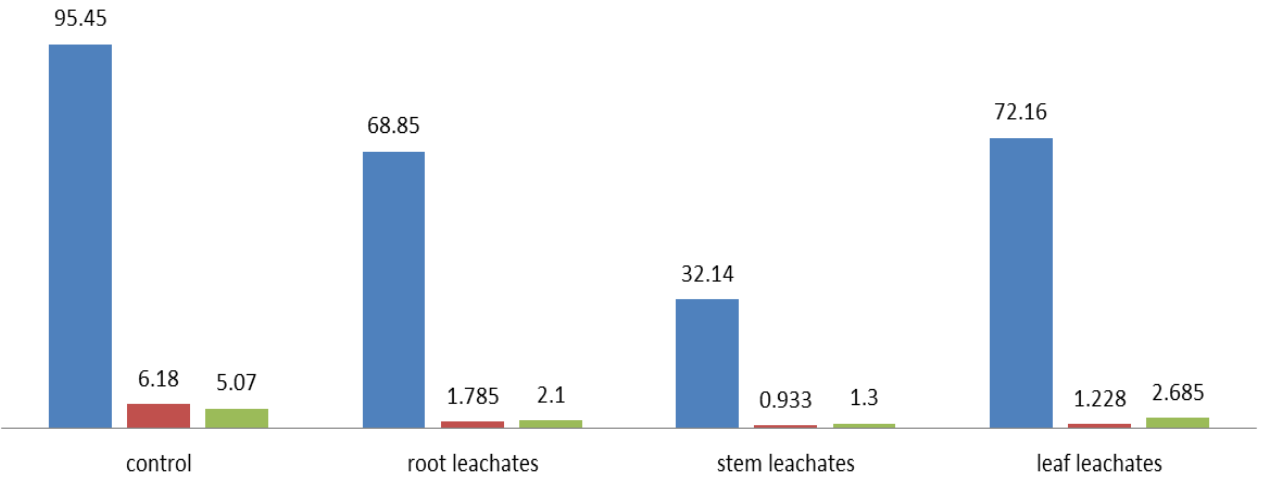

Graph-1: Graph showing inhibitory effects of Leachates of Euphorbia parviflora $\mathrm{L}$

Table-2: Table showing Results of Phytochemical Tests of Euphorbia parviflora $\mathbf{L}$

\begin{tabular}{|l|c|c|c|}
\hline \multicolumn{1}{|c|}{ Test } & Root & Stem & Leaves \\
\hline A)Water Extracts & \multicolumn{4}{|c|}{} \\
\hline Starch & $-\mathrm{ve}$ & $-\mathrm{ve}$ & $-\mathrm{ve}$ \\
\hline Proteins & $-\mathrm{ve}$ & $-\mathrm{ve}$ & $-\mathrm{ve}$ \\
\hline Tannins & $+\mathrm{ve}$ & $+\mathrm{ve}$ & $+\mathrm{ve}$ \\
\hline Saponines & $+\mathrm{ve}$ & $+\mathrm{ve}$ & $+\mathrm{ve}$ \\
\hline Anthroquinones & $-\mathrm{ve}$ & $-\mathrm{ve}$ & $-\mathrm{ve}$ \\
\hline Reducing Sugars & $-\mathrm{ve}$ & $-\mathrm{ve}$ & $-\mathrm{ve}$ \\
\hline B) Alcohol Extracts & \multicolumn{5}{|c|}{} \\
\hline Flavanoids & $+\mathrm{ve}$ & $+\mathrm{ve}$ & $-\mathrm{ve}$ \\
\hline Alkaloids & $+\mathrm{ve}$ & $+\mathrm{ve}$ & $+\mathrm{ve}$ \\
\hline Dragendorff'sReagent & $+\mathrm{ve}$ & $+\mathrm{ve}$ & $+\mathrm{ve}$ \\
\hline Mayer'sreagent & $-\mathrm{ve}$ & $-\mathrm{ve}$ & $-\mathrm{ve}$ \\
\hline Wagner'sreagent & $+\mathrm{ve}$ & $+\mathrm{ve}$ & $+\mathrm{ve}$ \\
\hline
\end{tabular}




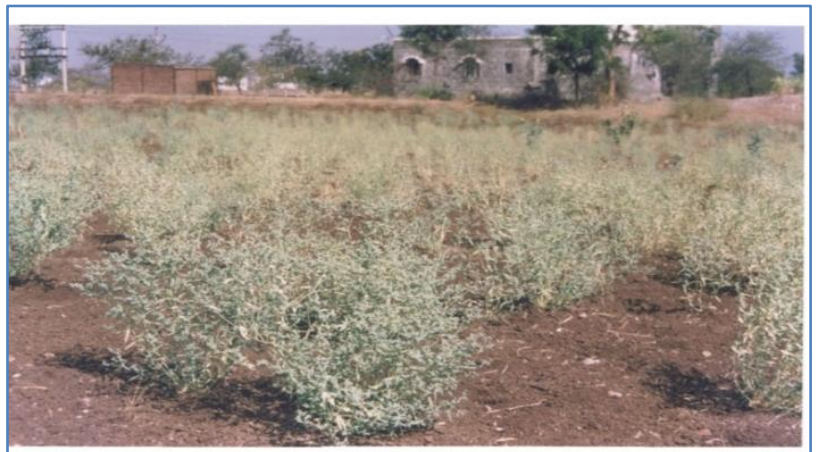

a) Habit of Euphorbia parviflora L.

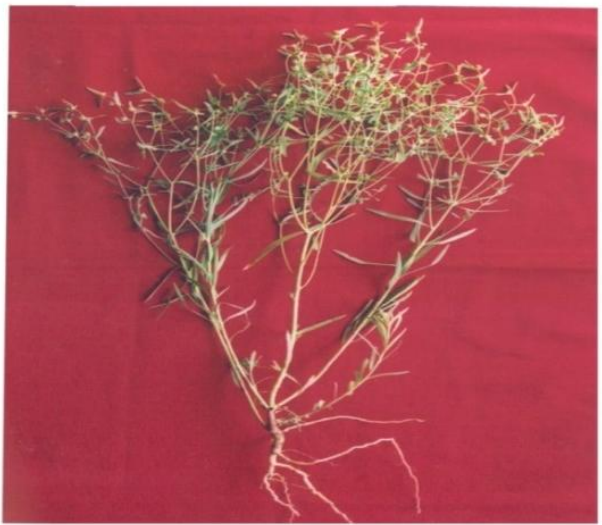

b) Individual Euphorbia parviflora plant.

Fig-1: Agriculture field showing Dominance of Medicinal plant weeds Euphorbia parviflora $\mathbf{L}$

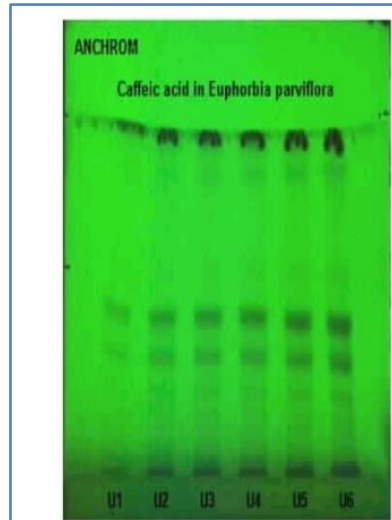

Image (254 nm)

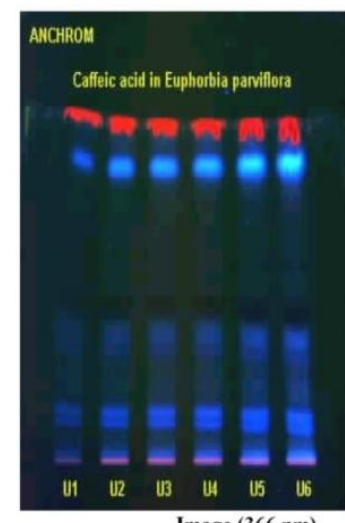

Image (366 nm)
Fig-2: HPTLC Plate showing detection of Caffeic acid from Euphorbia parviflora $\mathbf{L}$

\section{REFERENCES}

1. Bansal GL, Bhan VM. Status of research of allelopathy and future scope of in India. Indian Journal of Agricultural Science. 1993; (63): 769-776.

2. Bhatt BP, Chauhan DS. Allelopathic effects of Quercus spp. On crop of Garhval Himalaya. Allelopathy Journal. 2000; (7): 265-273.

3. Narwal SS. Allelopathy in Crop Production: Jodhpur, India: Scientific Publishers. 1994; 288.

4. Prasad MNV, Subhashini P. Mimosin inhibited seed germination, seedling growth and enzymes Oryza sativa L.Journal of Chemical Ecology. 1994; (20): 1989-1696.

5. Rice EL. Allelopathy-An update. Botanical Review. 1979; (45): 1-93.

6. Tukey H B Jr; Loss of organic and inorganic materials by leaching from leaves and other ground plant parts. International Atomic Energy Agency, Vienna. 1962; 289-302.

7. Tukey H B Jr; The occurrence of leaching from above ground plant parts and nature of the material. Leached Proc. XVI International Horticultural Congress. 1964; (4):164-153.

8. Singh A. Irradiation of polymer blends containing a polyolefin. Radiation Physics and Chemistry. 2001 Jan 1;60(4-5):453-9.

9. Nadkarni KM. Indian meterica media Nadkarni and Co; 1927.

10. Chopra RN, Nayar SL and Chopra IC. Glossary of Indian medicinal plants (Vol. 1, pp. 138-139). New Delhi: Council of Scientific \& Industrial Research.1956:138-139.

11. Mathela CS. Allelochemicals in medicinal and aromatic plants, Allelopathy in Agriculture and forestry. 1994; (Eds., S.S. Narval and P.Tauro):213-228

12. Peach, Tracy KV. Modern Methods of Plant Analysis Springer Verlog Berlin. 1955; (2) 153-154.

13. Trease GE, Evans WC. Pharmacognosy; (10th Edn.) Bailer Tindall, London; 1972.

14. Fransworth. Handbuck der Dragenkunde. Wilhem Mudrich Verlog, Wein Band V.1960: 279-298.

15. Passera CA, Pedrotti G. Ferrari Chromatography. 1964; 14: 289. 